\title{
On Research of the Vehicle Conversion Effects on Dynamic Performance Degradation
}

\author{
Nabil Khettou ${ }^{1)}$ \\ Dragan Trifkovic ${ }^{1)}$ \\ Slavko Muždeka ${ }^{1)}$ \\ Aleksandar Grkic ${ }^{1)}$ \\ Sreten Perić ${ }^{1)}$
}

\begin{abstract}
Upon the vehicle conversion, the converter should ensure before putting the vehicle into service, that the modifications, carried out on the baseline vehicle, do not inhibit the ability of the converted vehicle to properly and surely perform its function. Any change to the vehicle weight distribution and center of gravity, which does not meet the manufacturer guidelines, may lead to excessive body roll and possible rollover. The aim of this work is to estimate degradation of the vehicle dynamic characteristics by recording on-road vehicle parameters on both baseline and converted vehicle. The experiments were carried out for the vehicles performing a double lane change maneuver at different speeds. The obtained results show excessive roll angle, lateral acceleration and suspension deformation, which suggests a higher tendency of the vehicle to instability and loss of control.
\end{abstract}

Key words: vehicle, terrain vehicle, vehicle modification, vehicle stability, roll angle stability, vehicle testing, field measurements, testing in use, dynamic characteristics.

\section{Introduction}

$\mathrm{O}$ NE of the main activities of the Military Technical Institute (VTI) is the modification and conversion of mobile platforms in order to outfit land forces with different mobile solutions at low cost. VTI engineers are increasingly using vehicle conversion in order to quickly and efficiently develop new mobile platforms that are intended to accomplish different military missions. However, it should be emphasized that any changes to the baseline vehicle which do not meet the manufacturer guidelines may severely affect the ability of the vehicle to properly accomplish its function. Thus, before placing any converted vehicle into use, the converter should evaluate degradation of dynamic performance of the vehicle. The main issues upon vehicle conversion are the modifications of the vehicle weight distribution, vehicle kerb weight and the position of the center of gravity $(\mathrm{CoG})$ [1][2][3]. These changes can lead to excessive body roll, poor handling performances and reduced lateral stability[4].

VTI engineers converted the ground wheeled vehicle Land Rover Defender 110 into an intelligent mobile platform for ground border surveillance and reconnaissance called MIP (Figure 1). The conversion consisted of the integration of a sensor box, comprising a TV and thermal camera, laser telemeter, navigation device, digital compass and a short range ground radar, all mounted on the top of a telescopic mast fixed to the vehicle chassis. The added equipment considerably changes the weight of the vehicle, weight distribution and vehicle center of gravity height. A high fidelity multibody simulation model of the Defender 110 was previously built in order to predict the dynamic performance degradation of the vehicle after the modification [5] [6]. However, only field tests can provide real representation of the complex interaction between the vehicle and the integrated equipment.

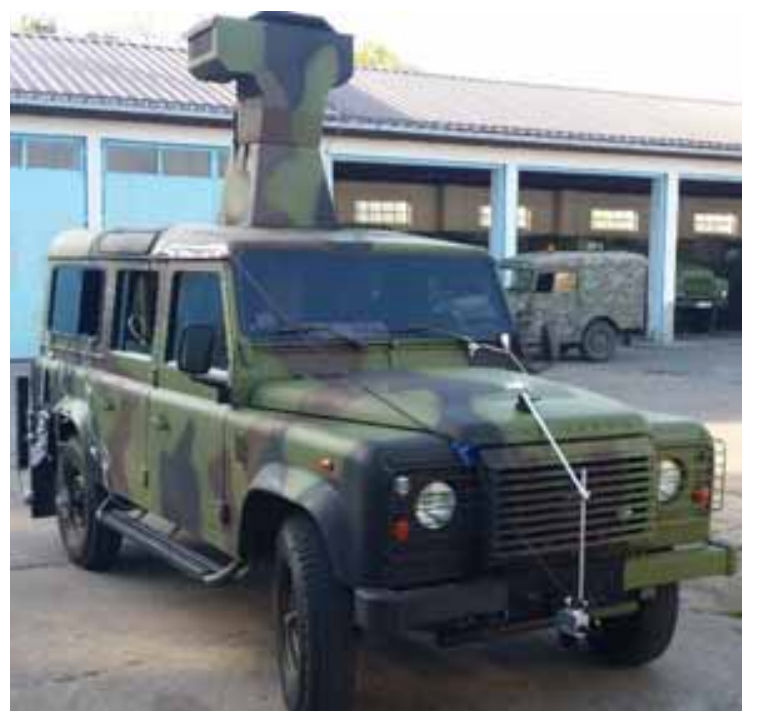

Figure 1. Surveillance and reconnaissance platform MIP

In this paper, we will be presenting the experimental results obtained after testing both the baseline vehicle and the prototype of the converted vehicle MIP considering two configurations of the telescopic mast. The instrumented

\footnotetext{
1) University of Defense, Military Academy, Generala Pavla Jurišića Šturma 33, 11000 Belgrade, SERBIA

Correspondence to: Nabil Khettou; e-mail: nabil.khettou@gmail.com
} 
prototype was equipped with different sensors to record dynamic parameters while the vehicle is running a double lane change maneuver. The experimental results are compared with those obtained for the baseline vehicle before the modification [7] in order to estimate degradation of dynamic characteristics. The effect of the mast elevation was also investigated by comparing experimental results of the converted vehicle MIP with telescopic mast at different heights.

\section{Field measurements}

The MIP prototype was tested using the instrumented vehicle when performing a double lane change maneuver according to STANAG-4357[8]. The tests were carried out on a dry airport pavement and the vehicle was checked so that it operates according to the manufacturer's instructions, especially suspension and tire conditions. In order to record the required signals, different sensors and transducers were installed on the vehicle (Fig.2). Position of the CoG of the baseline and the converted vehicle are given in Table 1 measured with reference to a coordinate system located at themid contact point between the left front wheel and the ground.

Table 1. Principal technical characteristics of the vehicles to be tested

\begin{tabular}{|c|c|c||}
\hline Model & $\begin{array}{c}\text { Land Rover } \\
\text { DEFENDER 110 }\end{array}$ & $\begin{array}{c}\text { Converted } \\
\text { DEFENDER MIP }\end{array}$ \\
\hline \hline Wheel base [mm] & \multicolumn{2}{|c|}{$2794 \mathrm{~mm}$} \\
\hline Track width [mm] & \multicolumn{2}{|c|}{$1486 \mathrm{~mm}$} \\
\hline Unloaded Weight & $2125 \mathrm{~kg}$ & 2750 \\
\hline Front suspension & \multicolumn{2}{|c|}{ Live beam axle } \\
\hline Rear suspension & \multicolumn{2}{|c|}{ Live beam axle } \\
\hline Axle ground clearance [mm] & \multicolumn{2}{|c|}{$250 \mathrm{~mm}$} \\
\hline Tire size & \multicolumn{2}{|c|}{$235 / 85 \mathrm{R} 16$} \\
\hline $\begin{array}{c}\text { CoG vertical position (from } \\
\text { ground) [mm] }\end{array}$ & $1000 \mathrm{~mm}$ & 1027 \\
\hline $\begin{array}{c}\text { CoG longitudinal position (from } \\
\text { front axle) [mm] }\end{array}$ & $1400 \mathrm{~mm}$ & 1598 \\
\hline \hline
\end{tabular}
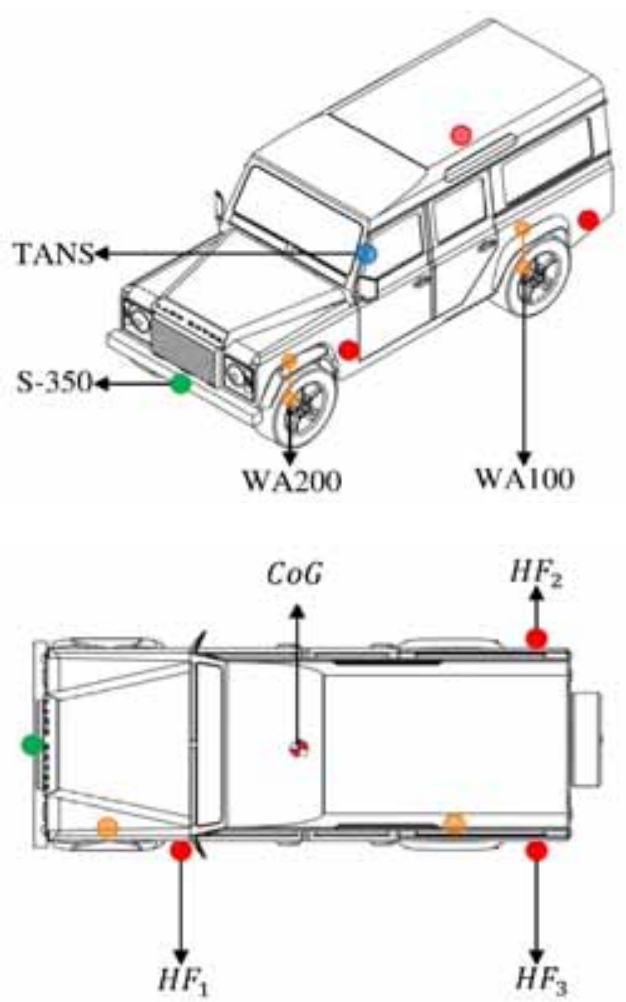

Figure 2.Vehicle measurement positions
The triaxial navigational sensor (TANS), which gives simultaneous measurement in up to 6 axes (3-axes gyro and 3axes accelerometer) was installed near the vehicle's CoG. Three laser height sensors $\left(\mathrm{HF}_{1}, \mathrm{HF}_{2}, \mathrm{HF}_{3}\right)$ were installed on the vehicle body at three different locations to measure pitch and roll angles by a simple trigonometric calculation as follows:

$$
\begin{gathered}
\theta_{x}=\frac{H_{1}-H_{2}}{a} \\
\theta_{y}=\frac{H_{1}-H_{2}}{a}
\end{gathered}
$$

Where $\theta_{x}$ is the roll angle, $\theta_{y}$ is the pitch angle and $H_{1}$, $H_{2}$ and $H_{3}$ are chassis heights measured by $\mathrm{HF}_{1}, \mathrm{HF}_{2}$ and $\mathrm{HF}_{3}$ sensors, respectively.

The optical sensor S-350 was mounted at the front bumper and used to measure vehicle longitudinal and lateral velocity. All the above mentioned sensors are manufactured by KISTLER. HBM's inductive displacement transducers WA100 and WA200 were mounted at the left front and rear springs to measure relative displacement chassis/axle. A displacement sensor was mounted on the steering rod to record steering wheel displacement. The data were recorded at $50 \mathrm{~Hz}$ sampling rate. Sensor positions and measurement parameters are defined in Table 2 . The position of each sensor was determined according to its technical characteristics, standard tests to be performed or measurement parameter requirements.

\begin{tabular}{|c|c|c|c|c|}
\hline Sensor & Position & Channel & Measure & Symbol \\
\hline $\mathrm{HF}_{1}$ & left front chassis & 1 & \multirow{3}{*}{$\begin{array}{l}\text { roll angle } \\
\text { pitch angle }\end{array}$} & \multirow{3}{*}{$\begin{array}{l}\theta_{x} \\
\theta_{y}\end{array}$} \\
\hline $\mathrm{HF}_{2}$ & right rear chassis & 1 & & \\
\hline $\mathrm{HF}_{3}$ & left rear chassis & 1 & & \\
\hline \multirow{6}{*}{ TANS } & \multirow{6}{*}{$\mathrm{CoG}$} & 2 & $\begin{array}{c}\text { longitudinal accelera- } \\
\text { tion }\end{array}$ & $a_{x}$ \\
\hline & & 3 & lateral acceleration & $a_{y}$ \\
\hline & & 4 & vertical acceleration & $a_{z}$ \\
\hline & & 5 & roll velocity & $w_{x}$ \\
\hline & & 6 & pitch velocity & $w_{y}$ \\
\hline & & 7 & yaw velocity & $w_{z}$ \\
\hline \multirow{2}{*}{ S-350 } & \multirow{2}{*}{ mid front chassis } & 8 & longitudinal velocity & $v_{L}$ \\
\hline & & 9 & lateral velocity & $v_{Q}$ \\
\hline WA200 & left front spring & 10 & displacement & $d_{1}$ \\
\hline WA 100 & left rear spring & 11 & displacement & $d_{2}$ \\
\hline SA & steering rod & 12 & steering angle & $\alpha$ \\
\hline
\end{tabular}

Table 2. Measurement parameters and sensor positions

Data acquisition scheme used for the field measurement is illustrated in Fig.3. The configured measurement chain consists of 8 sensors which are connected to the universal amplifiers MX840. Collected digital data from the amplifiers are sent to the laptop computer via Ethernet network. CATMAN software was installed on the in-board laptop computer for real time processing and visualization of the recorded data. 


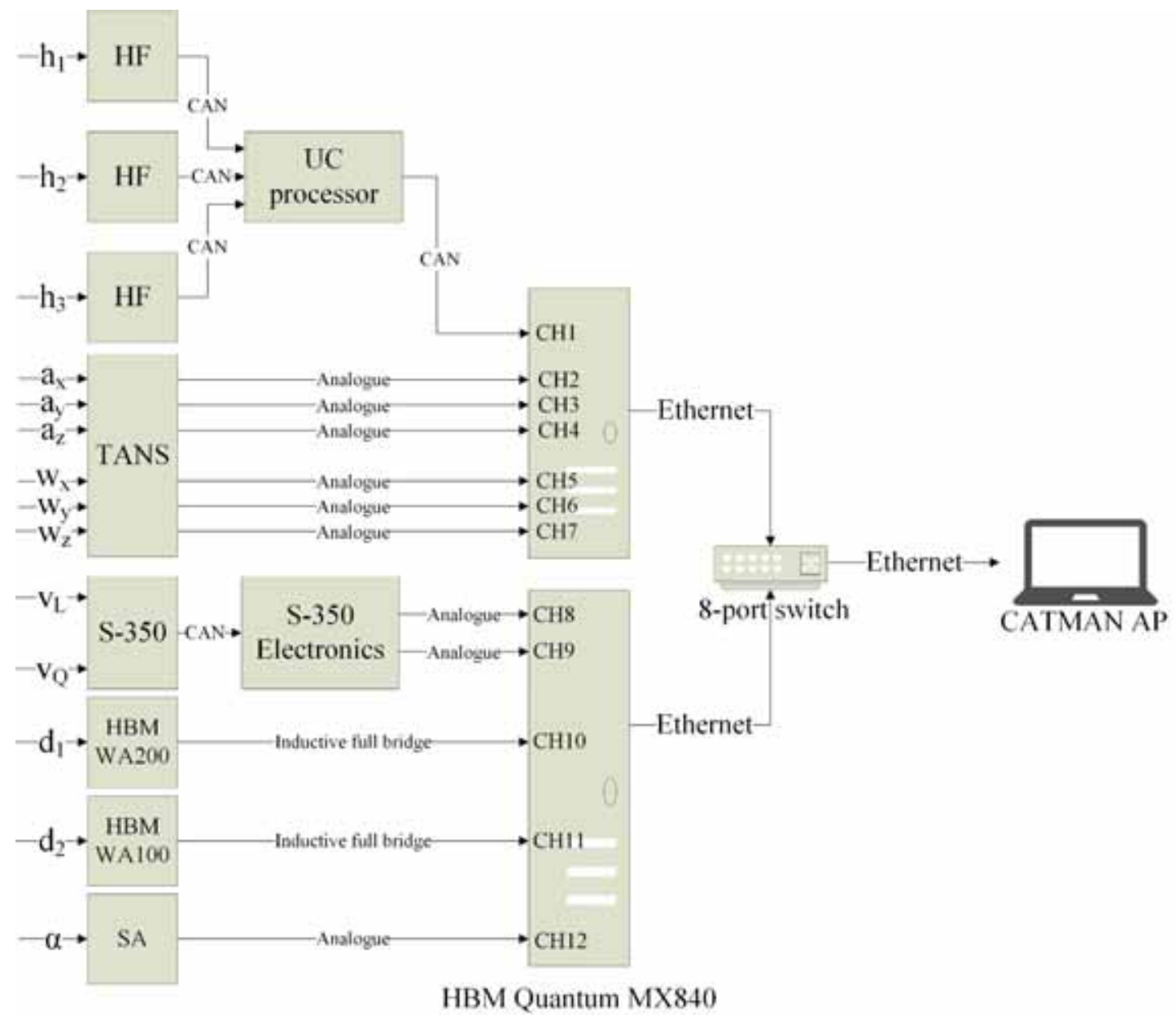

Figure 3. Block diagram of the data acquisition scheme

\section{Double Lane Change test}

The double lane change maneuver is used to evaluate handling dynamics and stability of the vehicle. The maneuver consists of switching the vehicle from one lane to another and back to the initial lane without hitting any of the cones defining the track (Fig.4). Depending on the vehicle width, different dimensions of the double lane change track used in this paper are defined by STANAG-4357 [8], as follows:

$$
\begin{aligned}
& W_{1}=2.2 \mathrm{~m} \\
& W_{2}=2.4 \mathrm{~m} \\
& W_{3}=2.6 \mathrm{~m} \\
& L_{0}=3.5 \mathrm{~m}
\end{aligned}
$$

Section $1=15 \mathrm{~m}$

Section $2=30 \mathrm{~m}$

$$
\begin{aligned}
& \text { Section } 3=25 \mathrm{~m} \\
& \text { Section } 4=25 \mathrm{~m} \\
& \text { Section } 5=15 \mathrm{~m}
\end{aligned}
$$

Steady state should be reached before the vehicle crosses the first section of the test. The vehicle is driven along a straight line at the maximum desired speed of $50 \mathrm{~km} / \mathrm{h}$. Pitch and roll angles are carefully controlled so that the vehicle begins the test at 0 degree pitch and roll angles. The longitudinal speed, pitch and roll angles of the vehicle were controlled based on driver skills, vehicle inboard instrument and the measured parameters obtained from S-350, HF1, HF2 and HF3 sensors. After entering the first section of the test track, throttle is maintained and the test is accomplished at the constant velocity. The test finishes when the vehicle regains its initial steady state. In order to drive the vehicle as safely as possible, higher speeds were not attempted because the vehicle was not equipped with a safety system to prevent roll over.

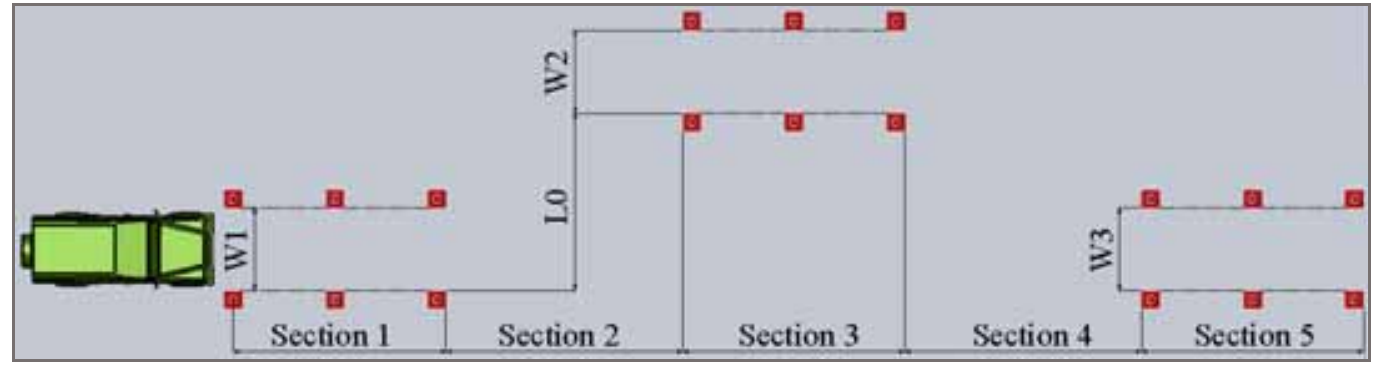

Figure 4. Double lane change test track 


\section{Results and discussion}

The obtained results for both the baseline vehicle and the converted vehicle MIP are shown in Figures 5 and 6. Fig.5 represents the observed parameters: roll angle, roll velocity, yaw velocity and front left spring displacement for the baseline vehicle (1) and the MIP with telescopic mast at marching position (2). The vehicles perform double lane change maneuver at $50 \mathrm{~km} / \mathrm{h}$. The obtained results show increasing values of the observed parameters, especially the roll angle which is a direct measure of the vehicle lateral stability.

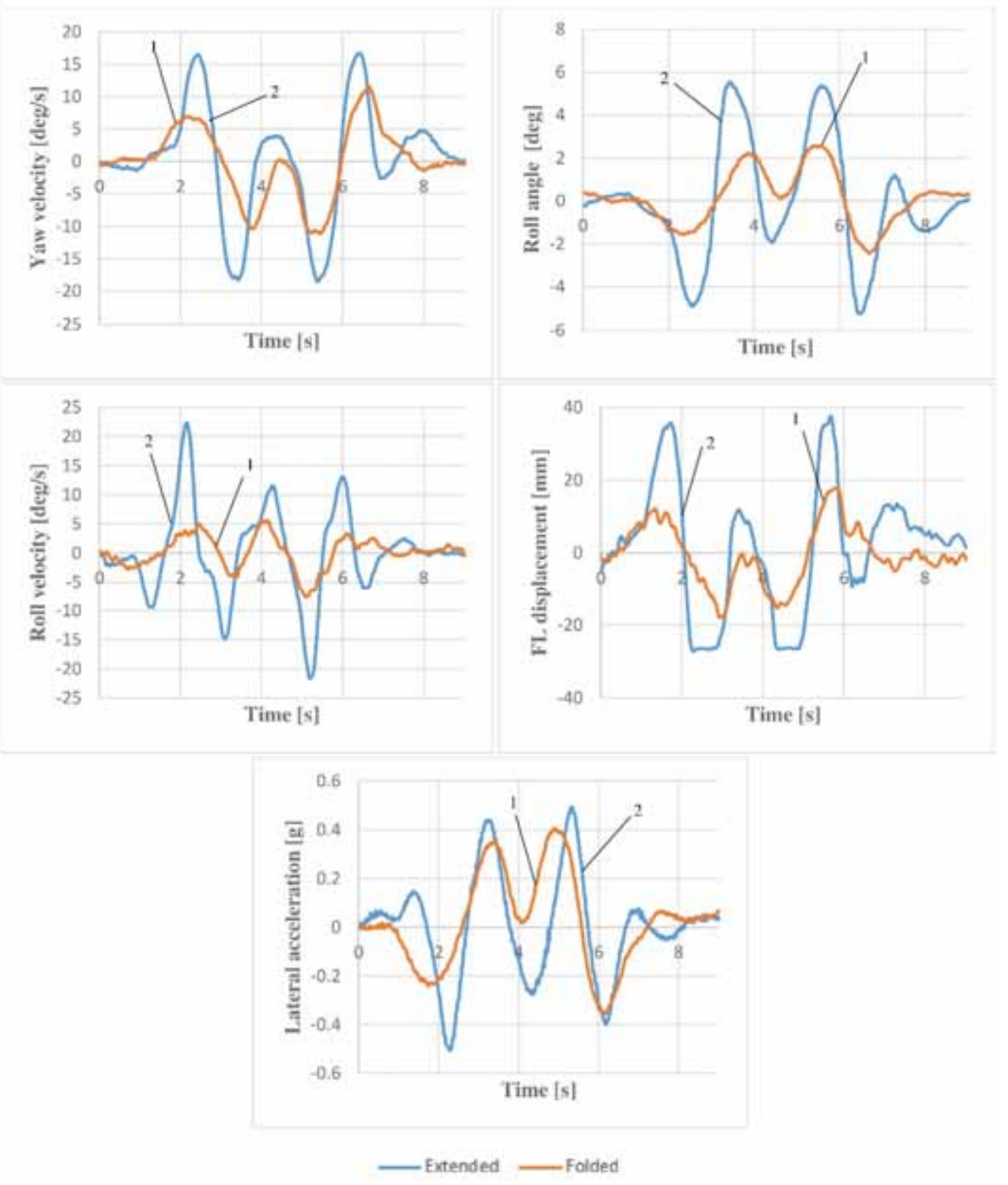

Figure 5. Experimental results of the converted and the baseline vehicle (Double lane change at $50 \mathrm{~km} / \mathrm{h}$ )

Table 3 shows that the added equipment yields considerably higher RMS (root mean square), lateral acceleration and maximum roll angle, which causes the vehicle to be more susceptible to rollover during a double lane change maneuver. In the present case, RMS lateral acceleration and maximum roll angle of the folded configuration of the vehicle increased by 16 and 114 per cent respectively with respect to the baseline vehicle.

Table 3. Calculated RMS lateral acceleration and maximum roll angle for baseline vehicle and MIP at folded configuration performing double lane change at $50 \mathrm{~km} / \mathrm{h}$

\begin{tabular}{|c|c|c||}
\hline \hline Parameter & $\begin{array}{c}\text { RMS lateral acceleration } \\
{[\mathrm{g}]}\end{array}$ & $\begin{array}{c}\text { Maximum roll angle } \\
{[\mathrm{deg}]}\end{array}$ \\
\hline \hline Baseline vehicle & 0.18 & 2.57 \\
\hline Folded configuration & 0.21 & 5.52 \\
\hline
\end{tabular}

Fig.6 represents the same previously mentioned parameters for the folded (1) and the extended configurations (2) of the MIP running a double lane change maneuver at $40 \mathrm{~km} / \mathrm{h}$, with telescopic mast at 2-meter height from the vehicle roof (extended configuration). As it can be seen from the diagrams, it is found that extending the telescopic mast yields relatively higher values of the roll angle, roll velocity, lateral acceleration and front left spring deformation. RMS lateral acceleration and maximum roll angle of the extended configuration (Table 4) increased by 11 and 69 per cent respectively, in comparison with the folded configuration. It should be noticed that during the field measurement, the converted vehicle showed clearly higher propensity to instability and loss of control. 


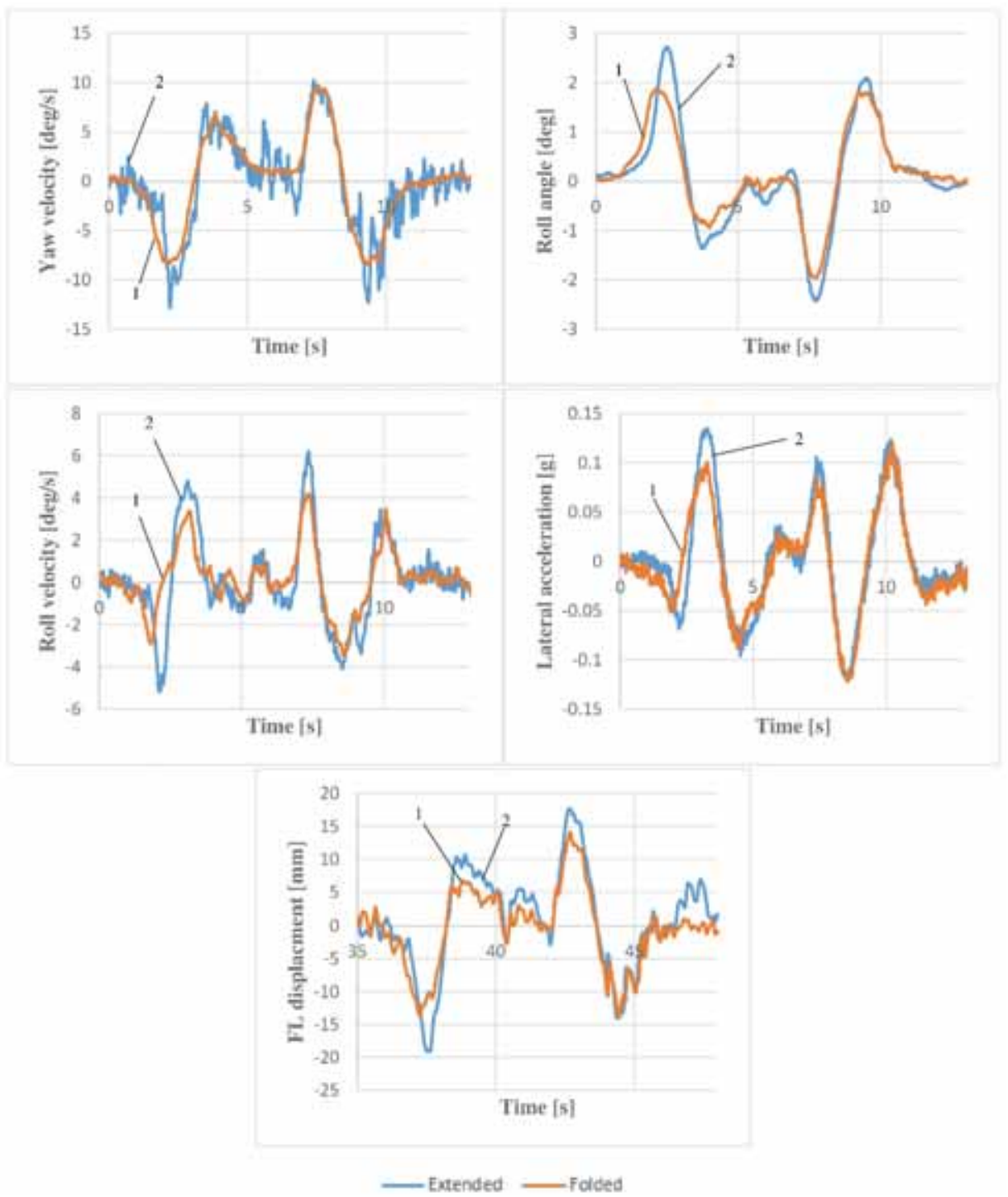

Figure 6.Experimental result of the extended and the folded configuration of the converted vehicle (Double lane change at $40 \mathrm{~km} / \mathrm{h}$ )

Table 4. Calculated RMS lateral acceleration and maximum roll angle for MIP at folded and extended configuration performing double lane change at $40 \mathrm{~km} / \mathrm{h}$

\begin{tabular}{|c|c|c||}
\hline Parameter & $\begin{array}{c}\text { RMS lateral acceleration } \\
{[\mathrm{g}]}\end{array}$ & $\begin{array}{c}\text { Maximum roll angle } \\
{[\mathrm{deg}]}\end{array}$ \\
\hline \hline Folded configuration & 0.051 & 1.61 \\
\hline Extended configuration & 0.057 & 2.72 \\
\hline
\end{tabular}

\section{Conclusion}

The experimental investigation carried out in the present work clearly revealed that upgrading ground wheeled vehicles, like Land Rover Defender, into an intelligent platform for surveillance and reconnaissance can have serious negative effects on lateral dynamics and stability of these vehicles. The present investigation revealed that during a double lane change maneuver, the converted vehicle experienced greater roll angles and lateral accelerations. These effects can be attributed to different reasons such as mass increase, change in mass distribution and higher CoG. During the filed tests, the MIP showed higher tendency to instability and loss of control which can lead to vehicle rollover and may cause occupants' injuries and fatalities. Future experiments will be carried out with the appropriate equipment in order to investigate the vehicle handling limits and define rollover threshold.

\section{Reference}

[1] ALLEN,R.: Estimation of Passenger Vehicle Inertial Properties and Their Effect on Stability and Handling, SAE Technical Paper 2003-010966, 2003.

[2] HEYDINGER,G., BIXEL,R., DURISEK,N., YU,E.: Effects of Loading on Vehicle Handling, SAE Technical Paper 980228, 1998.

[3] WHITEHEAD,R., TRAVIS,W., BEVLY,D., FLOWERS,G.: A Study of the Effect of Various Vehicle Properties on Rollover Propensity, SAE Technical Paper 2004-01-2094, 2004.

[4] KARNOPP,D.: Vehicle dynamics, stability, and control, 2nd ed. Boca Raton: Taylor \& Francis Group, 2013.

[5] KHETTOU,N., TRIFKOVIC,D., MUZDEKA,S.: Modeling and multibody simulation of land rover defender 110 ride and handling dynamics, Proceedings of the 7th International Scientific Conference on Defensive Technologies OTEH 2016, 6-7 October, 2016, Belgrade, SERBIA, ISBN 978-86-81123-82-9, pp.223-230.

[6] KHETTOU,N., MUZDEKA,S., GRKIC,A.: Modelling and validation of ground vehicle dynamics using multibody simulation, presented at the International Congress Motor Vehicles \& Motors, Kragujevac, 2016.

[7] KHETTOU,N., TRIFKOVIC,D., MUZDEKA,S.: Using Modelling and Simulation to Predict Dynamics of Converted Ground Vehicle, Defence Science Journal, 2016, Vol.66, No.5, pp. 509-516, .

[8] NATO: STANAG 4357-ALLIED VEHICLE TESTING PUBLICATIONS (AVTPS). 1991. 


\title{
Istraživanje uticaja konverzije vozila na degradaciju njegovih dinamičkih karakteristika
}

\begin{abstract}
Nakon izvršene konverzije vozila neophodno je, pre početka njegove eksploatacije, proveriti da li modifikacije koje su izvedene na osnovnom vozilu sprečavaju sposobnost konvertovanog vozila da pravilno i sigurno obavlja svoju funkciju. Svaka promena u razmeštaju masa i položaju težišta, koja nije u skladu sa uputstvima proizvođača osnovnog vozila, može prouzrokovati velike bočne nagibe i prevrtanje vozila. Cilj ovog rada je da se proceni degradacija dinamičkih karakteristika vozila merenjem parametara u vožnji, kako osnovnog tako i modifikovanog vozila. Obavljene su eksperimentalne vožnje vozila koje su obuhvatale manevar dvostruke promene vozne trake ("slalom vožnja") pri različitim brzinama. Dobijeni rezultati prikazuju velike uglove bočnog nagiba, poprečna ubrzanja i deformacije elemenata sistema oslanjanja, koji upućuju na tendenciju gubitka stabilnosti $i$ kontrole nad vozilom.
\end{abstract}

Ključne reči: vozilo, terensko vozilo, modifikacija vozila, stabilnost vozila, bočna stabilnost, ispitivanje vozila, terensko ispitivanje, ispitivanje u vožnji, dinamiičke karakteristike.

\section{Исследование эффектов преобразования транспортного средства на деградацию его динамических характеристик}

\begin{abstract}
После преобразования транспортного средства необходимо, перед началом его эксплуатации, проверить, были ли сделаны переоборудования на основном транспортном средстве и предотвращают ли они способность преобразованного транспортного средства, чтобы оно правильно и безопасно выполняло свою функцию. Любое изменение в размещении массы и положения центра тяжести, которое не находится в соответствии с инструкциями изготовителя базового транспортного средства, может вызвать серьёзные побочные склоны и опрокидывания транспортного средства. Цель данного исследования состоялась в том, чтобы оценить деградацию динамических характеристик транспортного средства путём измерения параметров во вождении, как базового транспортного средства, так и модифицированного транспортного средства. Были проведены экспериментальные вождения транспортного средства, которые включали манёвр двойной смены полосы движения ("слалом езда") на различных скоростях. Полученные результаты показывают широкие углы бокового наклона, поперечные ускорения и деформации элементов подвески, указывая на тенденцию потери устойчивости и управления транспортным средством.
\end{abstract}

Ключевые слова: транспортное средство, внедорожник, переоборудование транспортного средства, устойчивость транспортного средства, боковая устойчивость, испытания транспортного средства, полевые испытания, полевые испытания во вождении транспортного средства, динамические характеристики.

\section{Les recherches sur les effets de la conversion d'un véhicule sur la dégradation des performances dynamiques}

\begin{abstract}
Après la conversion d'un véhicule il est nécessaire avant de mettre le véhicule en service de vérifier que les modifications effectués sur le véhicule de base n'empêchent pas la capacité du véhicule converti de fonctionner correctement et sûrement. Toute modification de la répartition du poids du véhicule et le centre de gravité qui ne sont pas en accord avec les instructions du fabricant peur conduire à des roulis excessifs et causer de possibles retournements. Le but de ce travail est d'estimer la dégradation des caractéristiques dynamiques après la conversion en enregistrant les paramètres sur route du véhicule converti et ceux du véhicule de base. Les essais ont été effectués pour les véhicules effectuant un double changement de voie à des vitesses différentes. Les résultats obtenus montrent des valeurs supérieurs de l'angle de roulis, de l'accélération latérale et de déformation de suspension ce qui suggère une tendance augmentée du véhicule converti à l'instabilité et la perte du contrôle.
\end{abstract}

Mots clés: véhicule, véhicule de terrain, modification de véhicule, stabilité de véhicule, stabilité latérale, examen de véhicule, essai sur le terrain, essai de conduite, caractéristiques dynamiques. 